\title{
JNPH
}

Volume 7 No. 2 (Oktober 2019)

(C) The Author(s) 2019

\section{PERBEDAAN KADAR KOLESTEROL SEBELUM DAN SESUDAH TERAPI BEKAM BASAH DI KOTA BENGKULU}

\author{
DIFFERENCES OF CHOLESTEROL LEVELS BEFORE AND AFTER \\ WET THERAPY THERAPY IN BENGKULU CITY
}

\author{
RESVA MEINISASTI, JON FARIZAL, RINI PATRONI \\ JURUSAN ANALIS KESEHATAN POLTEKKES KEMENKES BENGKULU \\ JALAN INDRAGIRI NO. 03 PADANG HARAPAN KOTA BENGKULU 38225 \\ Email: jonfarizal77@gmail.com
}

\begin{abstract}
ABSTRAK
Latar Belakang: Kadar kolesterol yang berlebih dalam darah akan meningkatkan risiko terbentuknya plak yang dapat menimbulkan berbagai manifestasi klinis aterosklerosis. Konsekuensi utama aterosklerosis berupa jantung koroner, di Indonesia tercatat $1,5 \%$ dan di Bengkulu tercatat $0,6 \%$ orang yang mengalami penyakit jantung koroner. Selain pengobatan dengan menggunakan pengobatan farmakologi, salah satu metode tradisional yang diklaim dapat menjadi pilihan terapi ialah teknik bekam. Berbekam merupakan pengobatan Islam yang termasuk ke dalam kategori sunnah yang telah ditinggalkan (sunnah matrukah). Tujuan Penelitian ini untuk mengetahui perbedaan kadar kolesterol sebelum dan sesudah terapi bekam basah. Metode : Penelitian yang digunakan adalah pra eksperimen dengan rancangan one group pretest postest. Sampel terdiri dari 17 responden sesuai kriteria dengan metode purposive sampling. Dilakukan pengukuran kadar kolesterol, diberi perlakuan 3 kali terapi bekam basah dan diukur kembali kadar kolesterolnya dengan metode pemeriksaan CHOD-PAP. Analisis data menggunakan uji T Dependent. Hasil : terdapat penurunan kadar kolesterol dengan nilai rerata sebelum terapi bekam basah sebesar $167,41 \mathrm{mg} / \mathrm{dL}$ dan nilai rerata sesudah terapi bekam basah sebesar 124,59 mg/dL, maka terdapat perbedaan yang signifikan kadar kolesterol sebelum dan sesudah terapi bekam basah (CI 95\% 6.56, 69.09; $\mathrm{P}=0,003$ ). Kesimpulan : Terdapat perbedaan yang signifikan kadar kolesterol sebelum dan sesudah terapi bekam basah. Terapi bekam dapat dijadikan sebagai terapi komplementer sebagai upaya penurunan kadar kolesterol.
\end{abstract}

\section{Kata Kunci: Bekam basah, kadar kolesterol, CHOD-PAP}

\begin{abstract}
Background: Excess cholesterol level in blood will increase the risk of plaque formation which can cause various clinical manifestations of atherosclerosis. The main consequences of atherosclerosis in the form of coronary heart disease, in Indonesia recorded $1.5 \%$ and in Bengkulu recorded $0.6 \%$ of people who experience coronary heart disease. In addition to treatment using pharmacological treatment, one of the traditional methods that is claimed to be the choice of therapy is cupping technique. Berbekam is an Islamic medicine that belongs to the category of abandoned sunnah (sunnah matrukah). The purpose of this study was to determine differences in cholesterol levels before and after wet cupping therapy. Method: The study used
\end{abstract}


was a pre-experimental design with one group pretest posttest. The sample consisted of 17 respondents according to criteria with a purposive sampling method. Cholesterol levels were measured, treated 3 times wet cupping therapy and cholesterol levels were re-measured by the CHOD-PAP examination method. Data analysis using Dependent $\mathrm{T}$ test. Results: there was a decrease in cholesterol levels with an average value before wet cupping therapy of $167.41 \mathrm{mg} /$ $\mathrm{dL}$ and a mean value after wet cupping therapy of $124.59 \mathrm{mg} / \mathrm{dL}$, then there were significant differences in cholesterol levels before and after wet cupping therapy (CI 95\% 6.56, 69.09; $\mathrm{P}=$ 0.003). Conclusion: There were significant differences in cholesterol levels before and after wet cupping therapy. Cupping therapy can be used as a complementary therapy in an effort to reduce cholesterol levels.

\section{Keywords: Wet Cupping, cholesterol levels, CHOD-PAP}

\section{PENDAHULUAN}

Kolesterol merupakan bahan utama pada membran sel (Fahmy and Gugun, 2008). Sebagian besar kolesterol dihasilkan oleh tubuh bahkan sebanyak $80 \%$ dibuat oleh tubuh dan hanya $20 \%$ masuk bersama bahan makanan (Rini, Karim and Novayelinda, 2015).

Kadar kolesterol total yang dibutuhkan tubuh yaitu sebanyak $200 \mathrm{mg} / \mathrm{dl}$. Apabila melebihi dari $200 \mathrm{mg} / \mathrm{dL}$ akan menyebabkan hiperkolesterolemia, apabila dibiarkan secara perlahan akan mengeraskan dinding pembuluh darah sehingga menghambat aliran darah dan dapat menyebabkan aterosklerosis (Rini, Karim and Novayelinda, 2015).

Aterosklerosis merupakan suatu plak ateromatosa atau fibrofatty flaques yang menonjol ke dalam dan menyumbat pembuluh darah. Adapun bentuk konsekuensi utama aterosklerosis dapat berupa hipertensi dan serangan jantung karena infark miokardium (Widodo, 2014).

Berdasarkan laporan World Health Organization (WHO) pada tahun 2005 tercatat sebanyak 17,5 juta (30\%) dari 58 juta kematian di dunia disebabkan oleh penyakit jantung dan pembuluh darah. Angka tersebut penyebab kematian antara lain disebabkan oleh serangan jantung (7,6 juta penduduk), Stroke (5,7 juta penduduk) dan selebihnya disebabkan oleh penyakit jantung dan pembuluh darah (4,2 juta penduduk). Berdasarkan seluruh data yang telah dikumpulkan dari WHO diperkirakan pada tahun 2015 kematian akibat penyakit jantung dan pembuluh darah meningkat menjadi 20 juta jiwa, dan tetap akan meningkat sampai tahun 2030 diperkirakan sebanyak 23,6 juta jiwa (Rini, Karim and Novayelinda, 2015), di Indonesia tercatat sebanyak $1,5 \%$ angka kejadian penyakit jantung koroner dan di Bengkulu terdapat $0,6 \%$ orang yang mengalami penyakit jantung koroner (Riskesdas, 2013). Penanganan kadar kolesterol yang tinggi menurut Perkumpulan Endokrinologi Indonesia (PERKENI) mencakup terapi farmakologis dan terapi non farmakologis. Terapi non farmakologis dapat digunakan dengan terapi bekam basah. Berdasarkan survei pendahuluan peneliti, terdapat 4 Klinik Terapi Bekam yang ada di kota Bengkulu, namun hanya 1 Klinik Terapi Bekam yang aktif dengan jumlah pasien terbanyak. Pondok Pengobatan Alternatif Miftahusyifa merupakan satu-satunya pondok pengobatan dengan jumlah pasien yang memiliki keluhan hiperkolesterolemia berjumlah 373 pasien. Berdasarkan latar belakang tersebut, penulis tertarik untuk mengetahui perbedaan kadar kolesterol sebelum dan sesudah terapi bekam basah.

\section{METODE PENELITIAN}

Penelitian ini merupakan penelitian Pra Eksperimen dengan rancangan one group pre test-post test. Penelitian ini telah dilaksanakan di Pondok Pengobatan Miftahusyifa dan Laboratorium Terpadu Poltekkes Kemenkes Bengkulu. Sampel penelitian ini diambil dengan metode Purpossive Sampling yang 
terdiri dari 17 orang responden.

\section{HASIL}

Tabel 1 Rerata kadar kolesterol sebelum dan sesudah terapi bekam basah

\begin{tabular}{ccc}
\hline Variabel & $\mathrm{N}$ & $\mathrm{Mean} \pm \mathrm{sd}$ \\
\hline Kadar & 17 & $167,41 \pm$ \\
kolesterol \\
sebelum & & 57,14 \\
terapi bekam \\
basah & & \\
\hline Kadar & 17 & $124,59 \pm$ \\
kolesterol & & 39,64 \\
sesudah \\
terapi bekam \\
basah
\end{tabular}

Tabel 1 menunjukkan nilai rerata kadar kolesterol sebelum terapi bekam basah 167,41 $\mathrm{mg} / \mathrm{dL}$ dan rerata kadar kolesterol sesudah terapi bekam basah $124,59 \mathrm{mg} / \mathrm{dL}$, maka dapat diambil kesimpulan bahwa ada penurunan kadar kolesterol sebelum dan sesudah terapi bekam basah.

Tabel 2 Hasil Analisis Uji T Dependent Kadar Kolesterol Sebelum dan Sesudah Terapi Bekam Basah

\begin{tabular}{|c|c|c|c|}
\hline Variabel & $\mathrm{N}$ & $\begin{array}{c}\text { Rerata } \pm \\
\text { sd }\end{array}$ & $\begin{array}{c}P \\
(\mathrm{CI} 95 \%)\end{array}$ \\
\hline $\begin{array}{l}\text { Kadar kolesterol sebelum } \\
\text { terapi bekam basah }\end{array}$ & 17 & $\begin{array}{c}167,41 \pm \\
57,14 \\
\end{array}$ & \multirow{2}{*}{$\begin{array}{r}0,003 \\
-\quad(16,56- \\
69,09)\end{array}$} \\
\hline $\begin{array}{l}\text { Kadar kolesterol sesudah } \\
\text { terapi bekam basah }\end{array}$ & 17 & $\begin{array}{c}124,59 \pm \\
39,64\end{array}$ & \\
\hline
\end{tabular}

Tabel 2 menunjukkan hasil ada perbedaan yang signifikan kadar kolesterol sebelum dan sesudah terapi bekam basah (CI $95 \%$ 6.56, 69.09; $\mathrm{P}=0,003$ ).

\section{PEMBAHASAN}

Penelitian yang sudah dilakukan, dihasilkan sampel yang mengalami penurunan kadar kolesterol berjumlah 16 orang (94\%). Responden yang mengalami kenaikan kadar kolesterol berjumlah 1 orang
$(5 \%)$. Kadar kolesterol yang meningkat terjadi pada responden berjenis kelamin lakilaki sebagai perokok aktif dengan IMT 29 (overweight). Meningkatnya kadar LDL disebabkan bahan kimia tertentu yang ditemukan dalam asap rokok, salah satunya akrolein. Akrolein dapat merusak HDL sehingga mengganggu tugas HDL dalam mengumpulkan kolesterol jahat atau LDL (Aji Sanhia, Damajanty, 2015).

Hasil penelitian ini menunjukkan bahwa adanya penurunan kadar kolesterol yang signifikan setelah terapi bekam basah. Hasil sesuai dengan penelitian oleh Sari pada tahun 2015 yang menjelaskan bahwa adanya perbedaan yang signifikan antara kolesterol sebelum dan sesudah di bekam, terapi bekam diindikasikan untuk penanganan gangguan darah, mengobati nyeri, peradangan, relaksasi fisik dan mental, varises pada pembuluh darah vena serta memberikan hingga 50\% peningkatan pada tingkat kesuburan. Demikian juga dengan penelitian senada yang dilakukan oleh Fitriyah pada tahun 2015 didapatkan hasil bahwa terapi bekam basah dapat menurunkan kadar kolesterol total pada klien diabetes mellitus tipe 2. Penelitian yang dilakukan oleh Widodo pada tahun 2014 menunjukkan adanya penurunan kadar kolesterol darah total sebanyak $39,25 \mathrm{mg} / \mathrm{dL}$ setelah dilakukan terapi bekam basah dan penelitian yang dilakukan oleh Akbar pada tahun 2013 menyatakan bahwa terapi bekam basah minimal harus dilakukan tiga kali untuk mendapatkan hasil yang lebih baik.

Pada penelitian ini terapi bekam basah diberikan sebanyak 3 kali dengan interval 14 hari antara bekam yang satu dengan bekam yang lainnya. Penelitian yang dilakukan oleh Hasan pada tahun 2014 menyatakan bahwa mekanisme yang mendasari efek terapi bekam basah terhadap penurunan kadar kolesterol adalah terbukanya barier kulit yang akan meningkatkan fungsi ekskresi kulit diantaranya mengeluarkan lipid dan substansi atau material yang bersifat hidrofobik. Demikian juga dengan penelitian yang dilakukan oleh Mustafa pada tahun 2012 menyatakan bahwa terapi bekam basah dapat 
mengekskresikan material hidrofilik dan hidrofobik salah satu contohnya adalah lipoprotein (kolesterol merupakan salah satu bagian lipoprotein darah).

Menurut penelitian yang dilakukan oleh Sayed pada tahun 2013 menyatakan bahwa terapi bekam basah memungkinkan terjadinya perlukaan kecil dan tipis pada permukaan kulit dan ditambah adanya tindakan vakumisasi sehingga memungkinkan terjadinya ekskresi melalui kulit secara artifisial yakni suatu proses ekskresi atau pengeluaran material melalui kulit yang dibuat dengan cara melakukan insisi atau perlukaan tipis pada permukaan kulit yang dikombinasi dengan adanya vakumisasi atau penyedotan.

Proses ini dikatakan sebagai analogi dari proses ekskresi yang dilakukan oleh organ ginjal. Komponen yang memungkinkan untuk diekskresikan melalui terapi bekam meliputi produk-produk sisa metabolisme tubuh, radikal bebas, substansi kimiawi dan biologi yang dilepaskan ke dalam cairan interstisial serta substansi hidrofilik dan hidrofobik (lipoprotein atau kolesterol). Berdasarkan penjelasan diatas dapat disimpulkan bahwa terapi bekam basah dapat menurunkan kadar kolesterol total dengan mengeluarkan cairan hidrofobik.

\section{KESIMPULAN}

Hasil penelitian ini menunjukkan bahwa Ada perbedaan yang signifikan kadar kolesterol sebelum dan sesudah terapi bekam basah.. Diketahui dari hasil analisis uji $\mathrm{T}$ dependent nilai $\mathrm{P}=0,003(\mathrm{P}<0,05)$.

\section{SARAN}

Diharapkan akan ada penelitian yang lain yang tujuannya sama tetapi hal yang diteliti adalah variabell yang lain.

\section{DAFTAR PUSTAKA}

Akbar, N. and Mahati, E. (2013) 'Pengaruh Bekam Basah Terhadap Kolesterol dan
Tekanan Darah pada pasien Hipertensi di Semarang', Media Medika Muda. Availableat:http://www.ejournals1.undi p.ac.id/index.php/medico/article/view/4 956.

Berg JM, Tymoczko JL, S. L. (2012) Biochemistry. 7th edn. New York: W. H. Freeman.

Dr.Hasdianah HR, M. S. (2014) Patologi dan Patofisiologi Penyakit. Yogyakarta: Nuha Medika.

Fitriyah, N. (2015) 'Pengaruh Terapi Bekam Basah Terhadap Kadar Kolesterol Total Pada Klien Diabetes Mellitus Tipe 2 di Desa Kaliwining Kecamatan Rambipuji Kabupaten Jember', Digital Repository UNEJ.

Gandasoebrata, R. (2010) Penuntun Laboratorium Klinik. 16th edn. Jakarta: Dian Rakyat.

Hasan, I., Alam, T. and Irshad, S. (2014) 'Management of High Blood Cholesterol Levels Through Cupping Therapy In A Clinically Healthy Young Men', Pharmtech Research, 4(January).

Irianto Koes (2014) 'Epidemiologi Penyakit Menular dan Tidak Menular', in Alfabeta. 1st edn. Bandung: Alfabeta.

Kasmui, D., Si, M. and Nabawi, K. T. (2012) Bekam Pengobatan Menurut Sunnah Nabi. Semarang: Pustaka Imam Asy Syafi'i.

Kusumasari, P. (2015) 'Hubungan antara Merokok dengan Kadar Kolesterol Total pada Pegawai Pabrik GulaTasikmadu Karanganyar', Teknolab.

Lefever Joyce (2008) Pedoman Pemeriksaan Laboratorium dan Diagnostik. 6th edn, buku kedokteran EGC. 6th edn. Edited by K. Ramona. Jakarta: Buku Kedokteran EGC.

Majid, B. (2009) Mujarab Teknik Penyembuhan dengan Bekam. Jakarta: PT.Buku Kita.

Aji Sanhia, Damajanty, J. (2015) 'Gambaran Kadar Kolesterol Low Density Lipoprotein (LDL) Pada Masyarakat Perokok Di Pesisir Pantai', e-Biomedik, 3(April). 